\title{
ETNOGRAFI ASTROLOGI DAKWAH ISLAM KEPULAUAN DI KESULTANAN TIDORE
}

\author{
Syarifudin \\ Fakultas Ushuluddin dan Dakwah IAIN Ambon \\ (E-mail: syarifiainambon99@gmail.com)
}

\begin{abstract}
This research deals with archipelagic Islamic astrology. The problem of this research focused on the identification of island Islamic astrology by integrating with modern astrology in the Tidore Sultanate as a contribution to healthy social change in the community. This study patterned phenomenology with an ethnographic approach. This study found that there are 9 types of black magic in the tradition of society if there is a social conflict, this medium of black magic is a nuisance to social life that ends in the death of the soul. In addition there are 14 white arts that have a major contribution to maintaining the physical and spiritual health of the Islamic community of islands in the city of Tidore. The role of archipelago Islamic astrology greatly influences people's thinking patterns in the process of cultural development and contributes in three aspects; 1). Science of astrology all aspects of life to determine the day to achieve success at work, 2). Determine good days for political, cultural and economic activities. Islamic astrology, especially for the people, is more about the astrology of elders than using modern people's thinking on aspects of death, bathing bodies, entering homes, weddings, and determining the good days and even influencing the color of politics. 3). Islamic astrology is used as a guide for the healing process of medical and non-medical diseases. Modern astrology is materialism Archipelago Islamic astrology is spirituality. The contribution of this study is to open integrated scientific insights, interconnection with multiparadigm insights to form an academic archipelago Islamic Astrology as a contribution to the development of science.
\end{abstract}

Key Word; Astrology, Islam, and the archipelago.

Abstrak

Penelitian ini berkaitan dengan ilmu astrologi Islam kepulauan. Masalah penelitian ini terfokus pada identifikasi ilmu astrologi Islam kepulauan dengan mengintragasikan dengan astrologi modern di Kesultanan Tidore sebagai kontribusi perubahan sosial yang sehat di tengah masyarakat. Penelitian ini bercorak fenomenologi dengan pendekatan etnografi. Penelitian ini menemukan ada 9 jenis ilmu hitam dalam tradisi masyarakat jika terjadi konflik sosial, media ilmu hitam ini sebagai pengganggu kehidupan sosial bermasyarakat yang berakhir pada kematian jiwa. Selain itu ada 14 ilmu putih yang memiliki kontribusi besar menjaga kesehatan jasmani dan rohani masyarakat Islam kepulauan di kota Tidore. Peran astrologi Islam kepulauan ini sangat memengaruhi corak berpikir masyarakat dalam proses pembangunan kebudayaan dan berkontribusi dalam tiga aspek; 1). Ilmu perbintangan semua aspek kehidupan untuk menentukan hari 
untuk mencapai kesuksesan dalam bekerja, 2). Menentukan hari-hari baik untuk melakukan aktivitas politik, budaya, dan ekonomi. Astrologi Islam khususnya bagi masyarakat lebih banyak mengutakan ilmu perbintangan orang tua-tua dari pada menggunakan cara berpikir orang modern pada aspek kematian, mandi jenazah, masuk rumah, acara pernikahan, dan penentuan hari baik dan bahkan ia sangat memengaruhi warna politik. 3). Astrologi Islam digunakan sebagai petunjuk untuk proses penyembuhan penyakit medis dan non medis. Astrologi modern bersifat materialism Astrologi Islam kepulauan bersifat spiritualialitas. Kontribusi kajian ini untuk membuka wawasan keilmuan yang terintegrasi, interkoneksi dengan wawasan multiparadigma untuk merumuskan naskah akademik Astrologi Islam kepulauan sebagai kontribusi pengembangan ilmu pengetahuan.

Kata Kunci: Astrologi, Islam, dan kepulauan.

\section{A. Pendahuluan}

Etnografi dakwah dalam perspektif astrologi Islam kepulauan pesisir dalam kajian ilmiah masih sangat kurang dibahas oleh para ilmuan Islam sehingga bahan bacaan masyarakat terhadap lokal jenius Islam kepulauan sangat terbatas. ${ }^{1}$ Dalam sejarah Islam astrolog terkemuka, seperti Nasiruddin at-Tusi, Ulugh Beg, Al-Batanni, Ibnu Al-Haitham, Ibnu Al-Syatir, Abdur Rahman as-Sufi, Al-Biruni, Ibnu Yunus, Al-Farghani, Al-Zarqali, Jabir Ibnu Aflah, Abu Ma'shar, dan lainnya, telah memberi kontribusi bagi pengembangan astronomi dan astrologi modern. ${ }^{2}$

Ibnu Arabi mengungkapkan bahwa dunia makrokosmos seperti matahari, bulan dan planet-planet di alam semesta ini tidak hanya mempunyai pengaruh signifikan terhadap manusia selaku mikrokosmos, tetapi juga berpengaruh terhadap prilaku manusia. ${ }^{3}$ Wawasan ini membutuhkan kajian konparatif ilmu astrologi Islam kepulauan di Tidore juga memiliki pandangan yang sama untuk penentuan hari baik dan hari buruk yang berdasarkan pada kalender hijria. Dalam kajian Ibnu Arabi dalam kalender hijriah jadi rujukan untuk menentukan perhitungan bulan untuk tujuan tertentu.

${ }^{1}$ Ja'far ibnu Muhammad Abu Ma'shar al-Balkhi, al-Mudkhal al-Kabir ila ellm Ahkam Annujjum, Kitab ini terdiri dari 106 bab. mengungkapkan, ilmuwan Muslim terkemuka di abad ke-9 M itu terlahir pada 10 Agustus $787 \mathrm{M}$ di Balkh, Persia (sekarang Afganistan).

${ }^{2}$ Nicholas Champian, Astrology and Cosmology in the World's Religions, (New York University Press, London, 2012), h. 11.

${ }^{3}$ Titus Burckhardt, Astrologi Spiritual Ibnu 'Arabi (Cet. I; Jakarta: Risalah Gusti, 2011), h. 43. 
Penelitian ini berupaya melacak apa hubungan manusia sebagai microkosmos dengan alam semesta sebagai macrokosmos. Abu Ma'syar al-Falaki dan Abu Hayyillah al-Marzuqi menemukan bahwa adanya pengaruh dari hukumhukum general kosmos terhadap hukum-hukum kosmik yang bersifat praktis, misalnya dalam ketatanegaraan dan watak-watak dasar individu. Bagi sebagian kalangan, tak menutup kemungkinan pandangan semacam itu dinilainya sebagai bertentangan dengan fundamen-fundamen Islam; dan itu bukan urusan tulisan ini. ${ }^{4}$ Atas dasar inilah sehingga pada kesempatan ini kajian etnografi astrologi Islam kepulauan menjadi focus dalam kajian dakwah sebagai salah satu sturktur sosail dalam menggerakkan perubahan sosial melalui pendekatan etnografi realitas sosial kehidupan Islam kepulauan di kota Tidore kepulauan Provinsi Maluku Utara.

Etnografi astrologi Islam atau dikenal dengan ilmu perbintangan khas Islam kepulauan memiliki keunikan isu karena beberapa argumentasi mendasar sehingga ia menjadi sorotan dalam kajian ini antara lain; 1). Astrologi Islam Kepulauan sangat memengaruhi sebagian besar aspek kehidupan untuk menentukan hari baik untuk mencapai kesuksesan dalam kehidupan sosial, 2). Astrologi Islam Kepulauan dijadikan sebagai instrument penentuan hari-hari pemerintahan, sosial politik, agama, dan, budaya, dan ekonomi, 3). Astrologi Islam Kepulauan menjadi poros penyembuhan penyakit media dan non medis yang didierita masyarakat di kota Tidore.

Penelitian astrologi Islam kepulauan menelaah proses transformasi dakwah Islam dalam mendidik, menjaga kualitas spiritual untuk mencegah dominasi materialism dalam kehidupan sosial. Tujuan penelitian ini akan mengintegrasikan astrologi modern bersifat materialism dan astrologi Islam yang bersifat spiritual. Kajian ini berupaya menemukan wawasan keilmuan Astrologi Islam kepulauan yang terintegrasi, interkoneksi dengan astrologi modern dengan menggunakan

${ }^{4}$ Abu Ma'syar al-Falaki dan Abu Hayyillah al-Marzuqi, Astrologi Islam: Abu Ma'syar al-Falaki (787-886), Astronom Muslim hebat waktu itu. Di bagian belakang, dicantumkan buku at-Thali' a-Hadasy karya Abu Hayyillah al-Marzuqi. Buku ini diterbitkan oleh Mathba'ah Isa al-Babi al-Halabi, Mesir tanpa tahun. 
perspektif multiparadigma untuk membangun wawasan Astrologi Islam kepulauan sebagai kontribusi pengembangan ilmu pengetahuan. ${ }^{5}$

Motivasi besar dalam kajian ini untuk mendeskripsikan astrologi Islam kepulauan sebagai solusi kemanusiaan dalam menentukan arah dan haluan pola pikir masyarakat Tomagoba di Daerah Kesultanan Tidore. Fokus kajian ini untuk mengungkap tata cara menghitung hari baik dan buruk, dengan pendekatan etnografi astrological Islam kepulauan yang berkaitan dengan prilaku sosial keagamaan khususnya tentang ilmu kebutuhan hidup, keselamatan, kenyamanan, pendidikan, kesehatan jasmani dan rohani, keamanan, dan politik yang diramalkan oleh orang pintar atau sering disebut orang tua-tua. Fokus kajian dalam artikel ini ada dua yakni; 1). Bagaimana realitas etnografi sosial astrologi Islam kepulauan dan, 2). Bagaimana peran astrologi Islam kepulauan dalam proses interaksi sosial kehidupan bermasyarakat.

\section{B. Tujuan Penelitian}

1. Untuk mendapatkan rumusan akademik deskripsi peta Astrologi Islam Kepulauan Moloku Kieraha di Kota Tidore sebagai brandmark dalam membuat referensi kebijakan pemerintah daerah dalam mewujudkan visi dan misinya yang selama ini belum ada konsep yang terintegrasi dan interkoneksi yang berkaitan dengan ilmu astrologi Islam.

2. Menemukan Wawasan astrologi Islam kepulauan di Moloku Kieraha khususnya di Kota Tidore sebagai pusat studi dan kajian astrologi Islam dikawasan Timur Indonesia yang bercorak Islam kepulauan sebagai khas kajian akademik Islam kepulauan. Dan untuk mendapatkan konsep astrologi Islam kepulauan di Kota Tidore.

\section{Metode Penelitian}

Corak penelitian ini adalah bersifat kualitatif dengan menggunakan perspektif Ahmad Al-Jaberi yang berasumsi bahwa pengetahuan fenomenologi itu multiparadigma burhani, bayani, dan irfani. ${ }^{6}$ Ketika pendekatan ini secara teknik berkerja secara integrasi, interkoneksi dalam preoses penterjemahan data dari

\footnotetext{
${ }^{5}$ David Hawthorne, V. K. Choudhry, Astrology for Life

${ }^{6}$ Nasrah, "Pengetahuan Manusia dan Epistemologi Islam", lihat juga Universitas Sumatera Utara Nasution, Khoiruddin, "Pengantar Studi islam" Yogyakarta: Tazzaff, 2009.
} 
fakta sosial yang tampak dalam keseharian masyarakat. ${ }^{7}$ Perspektif konsep penelitian integrasi dan interkoneksi, antara epistemologi bayani, irfani, dan burhani. ${ }^{8}$ Pendekatan kajian ini menggunakan metode tafsir sosial Tahlili yang memilih satu objek sosial khusunsya proses penerimaan informasi, proses memahami informasi dan proses prilaku terhadap informasi tersebut. Corak metode penelitian dengan mencermati satu fenomena sosial dari aspek memahami pesan, memaknai pesan, dan menjalankan pesan. ${ }^{9}$ Realitas sosial ditafsirkan secara alamiah kemudian merumuskannya menjadi tekstual, kontekstual dan antar tesktual.

Metode ini diperkuat oleh kajian etnografi sebagai metode untuk mencatat fenomena adat-istiadat, susunan masyarakat, ${ }^{10}$ bahasa dan identitas fisik dari suku-suku bangsa tertentu dengan pendekatan fenomenologi komunikasi budaya. Pendekatan fenomenologis digunakan untuk mengamati fenomena sosial alamiah. ${ }^{11}$ Perspektif etnografi merupakan kegiatan penelitian untuk memahami ekspresi interaksi sosial dalam bekerjasama dalam kehidupan sehari-hari. ${ }^{12}$ Etnogarafi adalah pelukisan yang sistematis dan analisis suatu kebudayaan kelompok, masyarakat atau suku bangsa yang dihimpun dari lapangan dalam kurun waktu tertentu. Untuk menggambarkan realitas sosial Islam kepulauan perspektif ini digunakan untuk mengidentifikasi ilmu astrologi Islam kepulauan secara alamiah dengan mengidentifikasi proses pemahaman, pemaknaan, dan prilaku keilmuannya di tengah masyarakat.

Model pengumpulan data penelitian ini juga mengkombinasikan teknik pengumpulan data dengan menggunakan dua strategi antara lain; metode FGD

7 Muhammad Zainuddin, Filsafat IImu Perspektif Pemikiran Islam, (Cet. II; Yogyakarta: Bayu Media, 2003), h. 241.

${ }^{8}$ Harun Nasution, Islam Rasional dan Gagasan dan Pemikiran, (Cet. Bandung: Mizan, 1996), h. 132

9 Baqir Al-Shadr, Metode Tahliliy,(metode tajzi'iy), Metode ini berusaha menjelaskan ekspresi sosial dari segi pemahaman, pemaknaan, dan prilaku dengan memperhatikan prilaku manusia dalam ayat-ayat Al-Quran sebagaimana tercantum di dalam mushaf.

${ }_{10}$ Koentjaraningrat dkk, Masyarakat Desa di Indonesia, (Cet. XIV; Jakarta, Gramedia, 1993), h. 54.

${ }^{11}$ Koentjaraningrat dkk, Metode-Metode Penelitian Masyarakat (Edisi Ketiga) (Cet. VII; Jakarta: PT Gramedia Pustaka Utama, 1987), h. 77.

${ }^{12}$ James P Spradley, Metode Penelitian Etnografi (Cet.II; Jakarta: Tiara Wacana, 2013), h. 93 
dengan pemuka masyarakat dan observasi, wawancara mendalam, ${ }^{13}$ kepada narasumber ahli, dan dokumentasi fakta-fakta lapangan. Teknik analisis data menggunakan konsep Haberman dan Milles dengan melakukan penyajian data, kodifikasi data, reduksi data, dan mengambil kesimpulan dari data pustaka dan data lapangan.

\section{Pembahasan}

\section{Topografi dan Demografi kota Tidore}

Penelitian ini berada di kelurahan Tomagoba kecamatan Tidore yang berlokasi tepat di kantor Walikota Tidore kepulauan yang memiliki jumlah penduduk sebanyak 18.677 jiwa. $^{14}$ Astrologi Islam wemale (Islam Pesisir) dan eluni (Islam Pegunungan) yang jarang dipublikasikan ini telah beratus-ratus tahun menjadi dokter di tengah masyarakat. ${ }^{15}$ Pemetaan astrologi yang akan dibahas dalam kajian ini di kota Tidore kecamatan Tomagoba dan kecamatan Gurabati yang terdiri dari 11 kelurahan.

Struktur topografi kota Tidore memiliki 10 pulau dengan kota Kepulauan Tidore dan juga umumnya daerah di Provinsi Maluku Utara mempunyai tipe iklim tropis, sehingga sangat dipengaruhi oleh iklim laut yang biasanya heterogen sesuai indikasi umum iklim tropis. Bentuk topografi kota Tidore seperti piramida. Gunung dan di bawah kaki gunung tinggal masyarakat pesisir. 90\% masyarakat tinggal di daerah pesisir dan 10\% tinggal di daerah pegunungan seperti di kelurahan Gurah Bunga tinggal dipegunungan yang udaranya sangat dingin. Di tempat ini diyakini oleh masyarakat alat pembuktian kota Tidore adalah kota yang memiliki kekuatan supranatural.

Astrologi diambil oleh cendekiawan Islam setelah runtuhnya Aleksandria ke Arab pada abad ke-7, dan pendirian kerajaan Abbasiyah di urutan 8. Khalifah Abbasiyah kedua, Al Mansur (754-775) mendirikan kota Baghdad untuk bertindak sebagai pusat pembelajaran, dan termasuk dalam rancangannya sebuah pusat penerjemahan perpustakaan yang dikenal sebagai Rumah Hikmah Bayt al-

\footnotetext{
${ }^{13}$ Jogianto, Metodologi Penelitian Sistem Informasi (Cet.II; Jogyakarta: Andi, 2008), h. 6

${ }_{14}$ Maswin M. Rahman, Mengenal Kesultanan Tidore, (Cet.I; Lembaga Kesultanan Keraton Limau Duko Kesultanan Tidore, 2006), h. 9.

${ }^{15}$ Risky Polisi (25 Tahun), Wawancara di rumahnya pada hari jumat 21 Juli 2017 jam 08:55 wit.
} 
Hikma, yang terus berlanjut menerima pengembangan dari ahli warisnya dan memberikan dorongan besar untuk terjemahan bahasa Arab-Persia dari teks astrologi Helenistik. Penerjemah awal termasuk Mashallah, yang membantu memilih waktu untuk berdirinya Baghdad, dan Sahl ibn Bishr, (alias Zael), yang teks-teksnya secara langsung berpengaruh pada ahli astrologi Eropa seperti Guido Bonatti pada abad ke-13, dan William Lilly di abad ke-17. Pengetahuan tentang teks-teks Arab mulai diimpor ke Eropa selama terjemahan Latin abad ke-12. ${ }^{16}$

\section{Etnografi Sosial Keagamaan.}

Pengertian etnografi dakwah dalam kajian ini adalah menggunakan perspektif Richard yang berpandangan bahwa etnografi adalah realitas kehidupan dan kebudayaan suatu masyarakat atau etnik, misalnya tentang adat-istiadat, kebiasaan, hukum, seni, religi, bahasa. ${ }^{17}$ Dari termoninologi ini Sultan Nuku yang disebut sebagai (Jo Barakti) juga memberikan definisi bahwa etnografi amal-amal manusia yang diekpresikan dalam bentuk astrologi kebudayaan, perlindungan SDA, dan perlindungan dari segala macam penjajahan materialis yang berpotensi merusak tradisi Islam kepulauan sebagai wawasan kebangsaan bangsa Tidore. ${ }^{18}$ Dari terminology ini muncul pertanyaan bagaimana realitas sosial keagamaan dewasa ini di Tidore kepulauan ?

Kondisi sosial keagamaan di Tidore Kepulauan khususnya dilokasi penelitian pada tahun 2015 masalah hukum sebesar 115 kasus, pada tahun 2016 jumlah kasus 116. Jumlah kasus secara umum sebanyak 363 kasus. Dari persoalan hukum jumlah kemiskinan secara umum di kota Tidore 325.399 jiwa. Kasus ini terdiri dari konflik supporter ternamen bola kaki, menuman keras saat pesta, dan pendukung pilkada yang banyak memproduksi problematika sosial. ${ }^{19}$ Dari persoalan patologi sosial sesuai hasil wawancara akibat criminal murnih, criminal ilmuhitam, dan criminal motif tertentu. Corak realitas sosial seperti ini diduga kuat pengaruh astrologi etnoscience yang berbeda dengan temuan science modern.

\footnotetext{
${ }_{17}^{16}$ Learning Theories An Educational Perspective Sixth Edition

${ }^{17}$ Richard, Etnografi Sosial keagamaan (terjemahan Prenada media Group: Cet. I; Jakarta: Prenada Media group, 2016), h. 32.

18 Maswin M. Rahman, Mengenal Kesultanan Tidore, (Cet.I; Lembaga Kesultanan Keraton Limau Duko Kesultanan Tidore, 2006), h. 11.

${ }_{19}$ Data yang dikutif pada BPS kota Tidore Kepulauan untuk semua kabupaten, penulis belum temukan data secara rinci perkecamatan tahun 2016.
} 
Astrologi Islam di Tidore kepulauan jika dibandingkan dengan kajian astrologi modern oleh Nani Jafa sebagai Dosen Jurusan Sejarah Universitas Khairun Ternate itu menjelaskan, teori bumi ini bulat (geosentris), pertama kali astrologi yang digagas Galileo-Galilei, ilmuwan terkenal Eropa pada abad pertengahan. Pada abad ke-16 Islam kepulauan di Tidore juga telah menggas ilmu astrologi untuk menentukan arah kiblat, puasa, ritual haji, tanda-tanda alam yang dikenal dengan teori kutika (ilmu perbintangan). ${ }^{20}$

Jika astrologi di Eropa menjadi polemik antara pemikiran ilmu pengetahuan yang diwakili oleh Copernicus dan pemikiran dogmatik yang dihembuskan pihak Gereja Katolik Roma, mendorong Kerajaan Spanyol (ketika itu masih berafiliasi dengan Portugis) mengutus Magellan untuk membuktikan kebenaran dua pemikiran yang sedang dipolemikkan itu sementara kesultanan Tidore telah menjadi konstruksi bangunan ilmu pengetahuan yang bersumber dari ajaran Al-Quran sehingga temuan-temuan para ilmuan relevan dengan astrologi para ulama yang dikembangkan di kesultanan Tidore.

Ekspedisi Magellan pun mulai dilakukan, namun sayangnya ia tidak sempat mencapai Maluku (Tidore) untuk menyaksikan ilmu astrologi Islam kepulauan di kota Tidore. Juan Antonio de Elcano (seorang sejarawan sekaligus navigator dalam pelayaran itu) lah yang melanjutkan ekspedisi itu hingga mencapai Pulau Tidore pada tahun 1521. "Dan, titik yang menguak kebenaran pemikiran Copernicus itu ternyata terletak di Pulau Tidore setelah de Elcano dengan kapal Trinidad dan Victoria berlabuh di pantai barat Pulau Tidore pada tahun itu. $^{21}$

Dia turut mengusulkan Sultan Tidore dan Walikota agar Tidore Kepulauan ditetapkan sebagai anggota delegasi mewakili Indonesia (Tidore) dalam pertemuan tersebut Termasuk keikutsertaan secara tetap. ${ }^{22}$ Sultan Tidore dan Walikota Tidore Kepulauan ditetapkan sebagai wakil Indonesia pada periode

${ }^{20}$ David Hawthorne, V. K. Choudhr, Astrology For Life: Haw To by for Own Vedic Astrologer A Practical Guide to creating and Intrepreting Horoscopes for Your self, for family, and Friends (Sunstar Publishing Group, 2000), h. 23.

${ }^{21}$ Nani Jafar, Sejarawan Maluku Utara, http://kabarpulau.com/berita-pulau-tidoretitik-pembenaran-teori-ilmu-pengetahuan-.html.

${ }_{22}$ Maswin M. Rahman, Mengenal Kesultanan Tidore, (Cet.l; Lembaga Kesultanan Keraton Limau Duko Kesultanan Tidore, 2006), h. 9. 
pertemuan ke-VIII dan seterusnya. Hal ini menurutnya perlu mendapat perhatian serius dari pemerintah Tidore Kepulauan dalam proses integrasi keilmuan untuk kemanusiaan.

Misi pembangunan Islam kepulauan di kota Tidore telah relevan dengan temuan para peneliti di seluruh dunia, dengan bersemangat terus berusaha menguak rahasia racun keong dalamkajian mereka mengndung obat. Keong memiliki racun yang bereaksi cepat dan ampuh untuk penyakit tertentu. Jika ilmu astrologi Islam kepulauan (etnoscience) di integrasikan dengan ilmu astrologi moderen maka terjadi paradigma baru dalam membangun pola pikir untuk mendetekti panyakit sosial yang sifatnya media dan non medis lebih efektif. Integrasi ilmu menjadi kekuatan baru dalam terhadap pengembangan ilmu astrologi sesuai dinamika problematika sosial di kota Tidore Kepulauan.

\section{Astrologi Islam Kepulauan.}

Pengertian astrologi berasal dari Bahasa Yunani yang terdiri dari dua kata astron yang berarti bintang dan logos artinya ilmu. Astrologi memberikan berbagai jasa dan layanan yang berkaitan dengan astrologi yang bisa digunakan untuk menunjang dan meningkatkan berbagai aspek dalam kehidupan. Kata "Astrologi" berasal dari bahasa Yunani yang terdiri dari dua kata, yakni: "Astron" yang artinya bintang dan "Logos" yang artinya ilmu. Jadi Astrologi adalah ilmu yang mempelajari tentang posisi bintang-bintang dan benda-benda langit lainnya, serta keterkaitannya dengan situasi dunia ataupun kepribadian serta kehidupan seorang manusia. Analisa astrologi didapat dari waktu dan lokasi yang tepat dari kelahiran seseorang ataupun suatu peristiwa. Tinjauan metafisik tentang astrologi bisa ditemukan dalam buku "The Secret Doctrine" yang diterbitkan pada tahun 1888.

Jadi makna astrologi adalah ilmu perbintangan. Terminologi Astrologi bagi orang Tidore adalah ilmu yang digunakan untuk keselamatan dunia dan akhirat dengan melakukan perhitungan bintal di langit dan kalender hijria bukan bulan berdasarkan tahun masehi. Astrologi Islam Kepulauan ini sebagai petunjuk dan metode dalam menghitung dan memprediksi pilihan kehidupan manusia sejak 
ia lahir sampai ia meninggal dunia berdasarkan pengalaman dan keyakinan yang mereka miliki. $^{23}$

Masyarakat Tidore percaya bahwa posisi bulan dan bintang itu memengaruhi emosional karakter manusia sejak ia lahir, mereka juga beranggapan bahwa peristiwa bumi sangat memengaruhi watak dan karakter prilaku manusia. Dalam perspektif orang tidore bahwa ilmu itu langsung dari Tuhan yang disebut Ilmu Laduni. Dengan ilmu laduni, bisa diketahui ilmu ma'rifat dengan amalan-amalan tertentu. Peta pusat ilmu hitam dan ilmu putih di Kao (Halmahera utara), Bacan (Halmahera selatan), Tidore, Ternate.

Dalam ilmu astrologi dibagi beberapa bagian antara lain adalah ilmu laduni, kassyaf, musyahadah, mukasyafah, dan ilmu ma'rifah. Kota Tidore sebelum ada rumah sakit modern ilmu astrologi berkembang pesat di negeri kesultanan Tidore, seperti Tahlilan, Ratib, mangaji tikar, Khutbah dibalik tabir, Urut Spiritual, Mimpi, Kemasukan, Suanggi, Ramuan bersalin, Ilmu Usul Diri, Orang Pintar, Garuda berkelapa dua, Ilmu Perang Maritim Kora-kora, inilah jihad kebudayaan Sultan Nuku dalam memproteksi masyarakat kota Tidore dari berbagai ancaman kebudayaan Eropa yang berwawasan materialisme.

Fokus kajian ini pada proses etnografi transformasi dakwah yang berkaitan dengan prilaku sosial keagamaan Islam kepulauan di kota Tidore. Kajian ini berada di kelurahan Tomagoba kecamatan Tidore yang berlokasi tepat di kantor Walikota Tidore kepulauan yang memiliki jumlah penduduk sebanyak 18.677 jiwa. ${ }^{24}$ Problematika sosial yang paling dominan memproduksi masalah adalah joget, miras, perkelahian antar sporter saat turnamen bola kaki dan konflik pendukung saat pilkada sedang berlangsung. Sedangkan pembunuhan sadis terjadi pelakunya dari orang luar bukan asli Tidore Kepulauan. ${ }^{25}$ Semua masalah sosial ini belum ada pemetaan sosial yang baik oleh para penyuluh karena materi dakwah yang disuguhkan kurang sesuai dengan masalah yang dihadapi

${ }^{23}$ L. Ophelia, Sukses Finansial Lewat Astrologi dan Peta Kehidupan (Cet. II; Jakarta: Kompas, 2010), h. 173.

24 Maswin M. Rahman, Mengenal Kesultanan Tidore, (Cet.l; Lembaga Kesultanan Keraton Limau Duko Kesultanan Tidore, 2006), h. 9.

${ }^{25}$ Risky Polisi (25 Tahun), Wawancara di rumahnya pada hari jumat 21 Juli 2017 jam 08:55 wit. 
masyarakat Islam kepulauan di kota Tidore kecamatan Tomagoba yang terdiri dari 11 kelurahan.

Konsep Sultan Nuku ingin menjadikan kota Tidore sebagai kota ilmu (madinatuilm), wawasan ini berpandangan bahwa Sumber Daya Alam akan habis dan negeri yang menguasasi ilmulah yang akan menjadi pemimpin di dunia ini. Sehingga pengertian Tidore difahami tempat tidurnya para ilmuan untuk mengkaji kekuatan laut dan darat sebagai model pembangunan. Sultan Nuku Memahami Marajal Bahraini Yaltaqiyan itu pertemuan air tawar dan air laut menjadi inspirasi untuk membangun wawasan ilmu astrologi Islam. Banyak Sumber Daya Laut di Tidore Kepulauan yang membutuhkan penelitian mendalam yang terintegrasi antara ilmu science dan ilmu agama sebagai perspektif untuk mengungkap peradaban ilmu Astrologi Islam yang dapat diakui sebagai bidang kajian ilmiah dalam bentuk kontribusi terhadap perkembangan dunia ilmu pengetahuan.

\section{Peran Astrologi Islam di Tidore}

Di balik penentuan hari libur tersebut ternyata ada sejarah yang menarik untuk diketahui. Contohnya di negara-negara Timur Tengah seperti Arab Saudi, hari Jumat dipilih sebagai hari libur. Alasannya, hari Jumat dianggap sebagai hari baik bagi umat muslim untuk beribadah. Dengan liburnya aktivitas di hari Jumat, masyarakat Arab Saudi yang mayoritas muslim memiliki banyak waktu untuk melakukan salat Jumat dan ibadah lainnya secara total. Berbeda lagi dengan bangsa Yahudi di Israel. Mereka menetapkan hari Sabtu sebagai hari libur lantaran hari Sabtu merupakan hari ibadah bagi mereka. ${ }^{26}$

Era kejayaan kesulatanan Tidore mayoritas penduduknya menikmati libur pekanan pada hari Ahad bukan istila hari Minggu. Mayoritas masyarakat libur pada hari Jum'at. Aktivitas sosial di mulai pada hari Ahad. Dalam Islam hari Jum'at adalah hari yang mulia, karena ada perintah-perintah khusus dari Nabi Muhammad SAW kepada umat Islam untuk mengamalkan amalan dan ibadah tertentu seperti membaca surat Al-Kahfi, Sholat Jum'at berjamaah serta ibadah lainnya.

\footnotetext{
${ }^{26}$ Mirna Lofthus, Astrologi Spiritual Aproach To Astrologi (Cet. II; Digitizet, 2010).
} 
Tradisi libur di hari Ahad berasal dari tradisi Romawi Kuno di Italia. Pada saat itu orang Romawi Kuno beribadah di hari Ahad. Oleh kerena itu, orang Romawi libur di hari Ahad. Selain itu, orang Romawi selalu menandai hari libur dan hari penting lainnya dengan warna merah. Waktu itu orang Romawi menguasai banyak Negara di Eropa. Kekuasaan Romawi sampai Belanda, Inggris, Prancis, Jerman, dan lain- lain. Tradisi libur di hari Ahad kemudian diterapkan di Negara-negara jajahan Romawi.

Negara Belanda kemudian menjajah Indonesia selama 350 tahun sehigga tradisi kerja Belanda menjadi kebiasaan masyarakat pada saat itu. Hal ini ditentang oleh Sultan Nuku yang tetap menjadikan hari jumat sebagai hari libur dan hari beribadah. Tradisi libur di hari Ahad tetap dipakai di banyak negara sampai sekarang karena pengaruh penjajhan. ${ }^{27}$ Hal ini berbeda dengan hasil perbintangan hari di masa pemerintahan Sultan Nuku menjadikan hari Jumat hari libur sedangkan hari ahat hari mulai bekerja. Karena perhitungannya hari ahad adalah hari pertama.

Sebelum Tahun 1960, tak pernah dijumpai nama hari yang bertuliskan MINGGU selalu tertulis hari AHAD. Kalender tempo dulu, masyarakat Tidore tidak mengenal sebutan Minggu. Mereka telah terbiasa dan terbudaya utk menyebut hari AHAD di dalam setiap pekan (7 hari) dan telah berlaku sejak Masa Kerjaan Sultan Nuku. Nama hari tersebut sudah menjadi kebiasaan dan terpola di dalam semua kerajaan di Indonesia. Semua ini adalah karena jasa positif astrologi interaksi budaya secara elegan dan damai serta besarnya pengaruh masuknya agama Islam ke Indonesia yang membawa penanggalan Arab Termasuk di kesultanan Tidore.

Berbeda dengan tradisi kata Minggu diambil dari bahasa Portugis, Domingo (dari bahasa Latin Dies Dominicus yang berarti "Dia Do Senhor", atau Hari Tuhan Kita). Dalam bahasa Melayu yang lebih awal, kata ini dieja sebagai Dominggu dan baru sekitar akhir abad ke-19 dan awal abad ke-20, kata ini dieja sebagai Minggu. Jadi, kita pasti paham siapa yang dimaksud Tuhan Kita, bagi yang beribadah di hari minggu.

\section{libur-kita.html}

http://www.muslimdaily.net/artikel/special-feature/kenapa-minggu-jadi-hari- 
Bagaimana ini bisa terjadi? Ada yang mengatakan dengan dana yang cukup besar dari luar Indonesia, dibuat membiayai monopoli pencetakan kalendar selama bertahun-tahun di Indonesia. Percetakan dibayar agar menihilkan (0) kata Ahad diganti dengan MINGGU. Setetah kalender jadi, lalu dibagikan secara gratis atau dijual obral (sangat murah) di tengah masyarakat. Dampaknya Masyarakat Indonesia secara tak sadar, akhirnya kata Ahad telah terganti menjadi Minggu di dalam penanggalan Indonesia. ${ }^{28}$

Pada masa Pemerintahan Sultan Nuku kalender hijria menjadi petunjuk umat. Pemerintahan Sultan Nuku sebagai ulama, cendikiawan, dan ilmuan di bidang pemerintahan dan astrologi sampai saat ini tetap diwarisi sebagian masyarakat. Salah satu ilmu yang digunakan adalah ilmu astrologi Islam yang digunakan sebagai ilmu strtaegi perang Nuku pada tahun 1876 dalam melawan Belanda. Sultan Nuku berdakwah menyebarkan pesan-pesan spiritual tidak hanya di satu tempat. Sebab ia adalah sosok panglima perang berkah atau Jou Barakati (istilah Bahasa Tidore), Sultan sangat dicintai rakyatnya karena budi pekertinya yang luhur dan ilmu astrologinya yang mendalam. Ia bergerilya di darat \& lautan dari pulau ke pulau sampai Papua, Seram, Buru, Haruku dan Ambon. Kekuatan astrologi Islam untuk menjaga kesehatan jasmani dan rohani masyarakat. ${ }^{29}$

Peran ilmu astrologi ini ada sebagian yang mencatat dalam satu buku ada juga yang telah menghafalnya tidak dicatat. Salah satu Tokoh Astrologi Islam yang tinggal di Kelurahan Ome bernama Om Nau sebagai panggilannya seharihari. Om Nau memiliki kitab astrologi untuk mengetahui perhitungan bintang untuk mengetahui jenis penyakit, obat, hari baik, dan waktu-waktu penentuan ibadah shalat, zakat, puasa, dan Ibadah haji. Ilmu ini dalam kajian Islam disebut ilmu falaq, tapi tafsiran terhadap astrologi Islam kepulauan meliputi segala aspek kehidupan. $^{30}$

Wawasan ini menggunakan paradigma berpikir integrasi. Corak berpikir integrasi memadukan cara pandangan rasionalisme (burhani), Empiris (Bayani),

\footnotetext{
${ }^{28}$ https://www.nahimunkar.org/kronologis-kata-hari-ahad-diganti-hari-minggu/

29 Maswin M. Rahman, Mengenal Kesultanan Tidore, (Cet.l; Lembaga Kesultanan Keraton Limau Duko Kesultanan Tidore, 2006), h. 19.

${ }_{30}$ Saturnius, Boekoe "Astrologie" Atawa Horoscoop: Ilmoe Bintang Kelahiran Boeat Mengetaoei Orang Poenja Sifat2, Watak, Tabeat, dan Nasib. (Cet.I; N.V. Java Ien Boe Kongsie, Semarang), h. 97.
} 
dan Irfani (intuisi). Paradigm ini sebagai perspektif untuk menterjemahkan realitas sosial etnografi astrologi Islam kepulauan di Tidore. Etnografi astrologi Islam kepulauan di kesultanan juga digunakan untuk mengetahui saat panen obat di laut dan di darat dengan menggunakan rumus perbintangan yang ditulis dan diwariskan secara turun-temurun baik secara lisan dan Tulisan oleh masyarakat Tidore yang dianggap memiliki keturunan yang menguasai ilmu tersebut. Ilmu ini sangat berkontribusi memengaruhi corak berpikir masyarakat dalam menentukan hari perkawinan, masuk rumah, musim bertani dan para nelayan.

Kota Tidore dikelilingi laut maka ia banyak menyimpan obat-obatan di dalam laut seperti keong racul dari dasar laut mampu memutus suplai oksigen ke sel tumor adalah salah satu cara untuk mencegah pertumbuhan sel. Tapi para dokter di rumah sakit universitas Zürich mengujicoba hal sebaliknya. Pembuluh darah yang diserang kanker dinormalisasi kemudian dibanjiri oksigen. Para ilmuwan mengharapkan, dengan cara itu bisa meningkatkan keampuhan kemotherapi dan radiasi dari bahan obatan dari laut. ${ }^{31}$ Tidore dengan luas laut dapat dijadikan sebagai pusat integrasi obat tradisional dan moderen sebagai kekuatan untuk menjaga kesehatan jasmani dan rohani.

\begin{tabular}{|c|c|c|}
\hline No & $\begin{array}{c}\text { Jenis } \\
\text { Astrologi }\end{array}$ & Manfaat \\
\hline 1 & Tahlilan & $\begin{array}{l}\text { Untuk memasuki rumah baru, dan kajian malam jumat } \\
\text { untuk mendoakan orang tua yang sudah meninggal. }\end{array}$ \\
\hline 2 & Ratib & $\begin{array}{l}\text { Bacaan zikir yang dilakukan untuk mentransformasikan } \\
\text { wawasan untuk meningkatkan kecerdasan spiritual. }\end{array}$ \\
\hline 3 & $\begin{array}{l}\text { Khutbah } \\
\text { dibalik tabir }\end{array}$ & $\begin{array}{l}\text { Jenis transformasi pengetahuan melalui suara dan tidak } \\
\text { melihat khatib yang memberikan khutbah. Tujuannya } \\
\text { untuk memberikan focus dan konsentrasi bagi jama'ah. }\end{array}$ \\
\hline 4 & $\begin{array}{l}\text { Urut } \\
\text { Spiritual }\end{array}$ & $\begin{array}{l}\text { Jenis pijat dan urut yang dipakai untuk menyembuhkan } \\
\text { luka bakar, terkena minyak panas, air panas dan patah } \\
\text { tulang. }\end{array}$ \\
\hline 5 & $\begin{array}{l}\text { Kemasukan } \\
\text { Jin }\end{array}$ & Ilmu yang mengganggu manusia dari jin dan manusia. \\
\hline 6 & Suanggi & Ilmu yang membahas tentang blac magic. \\
\hline 7 & $\begin{array}{l}\text { Ramuan air } \\
\text { bersalin }\end{array}$ & $\begin{array}{l}\text { Ramuan yang dipakai untuk istri yang bersalin dengan } \\
\text { mudah dan tidak sakit, tanpa masuk rumah sakit. }\end{array}$ \\
\hline 8 & Ilmu Usul & Ilmu yang membahas tentang hakikat diri manusia dari \\
\hline
\end{tabular}

${ }^{31}$ Obat Herbal Penyakit Alergi Ikan Laut, Temuan Obat Ampuh dari Dasar Laut, http://www.dw.com/ id/temuanobat-ampuh-dari-dasar-laut/av-19246758. 


\begin{tabular}{|c|l|l|}
\hline & Diri & lahir sampai ia meninggal dunia. \\
\hline 9 & Orang Pintar & $\begin{array}{l}\text { Tokoh masyarakat yang diyakini mengetahui dan } \\
\text { mampu memprediksi nasib manusia dan pencurian } \\
\text { dapat dideteksi secara supranatural. }\end{array}$ \\
\hline 10 & $\begin{array}{l}\text { Garuda } \\
\text { berkelapala } \\
\text { dua }\end{array}$ & $\begin{array}{l}\text { Filosofi Negara dan Kebangsaan di kesultanan Tidore } \\
\text { yang berasaskan aku adalah engkau dan kau adalah aku. } \\
\text { Ulama dan Umara itu sejajar. }\end{array}$ \\
\hline 11 & $\begin{array}{l}\text { Ilmu Perang } \\
\text { Maritim } \\
\text { Kora-kora. }\end{array}$ & $\begin{array}{l}\text { Ilmu yang digunakan untuk berlayar, mencari ikan, dan } \\
\text { ilmu untuk perang di lautan. }\end{array}$ \\
\hline 12 & $\begin{array}{l}\text { Jihad } \\
\text { kemerdekaan } \\
\text { Sultan Nuku. }\end{array}$ & $\begin{array}{l}\text { Menjaga masyarakat Tidore dari Kolonial, penjajahan } \\
\text { budaya, dan politik adu-domba. }\end{array}$ \\
\hline 13 & $\begin{array}{l}\text { Kota } \\
\text { Pendidikan } \\
\text { Astrologi. }\end{array}$ & $\begin{array}{l}\text { Misi Sultan Nuku menjadikan Tidore sebagai pusat } \\
\text { pendidikan astrologi sebagai bagian dari misi } \\
\text { perjuangannnya. }\end{array}$ \\
\hline
\end{tabular}

Kehadiran ahli astrologi Islam kepulauan di tengah masyarakat sangat berkontribusi dalam menjaga kesenjangan sosial bagi masyarakat yang kurang mampu dalam proses penyembuhan penyakitnya. Masyarakat dan pemerintah khususnya dinas kesehatan untuk merawat kesehatan masyarakat di Tidore Kepulauan. Peran-peran sosial para astologi local jenius antara lain; melihat jodoh, penyakit yang tidak bisa diobati oleh dokter, membaca doa selamat saat masuk rumah baru, ilmu hubungan intim, dan mendeteksi pencurian yang sulit ditemukan buktinya.

Kota Tidore terkenal dengan ilmu nujum (Ilmu Astrologi) dalam pemaknaan masyarakat Islam kepulauan ilmu orang pintar. Tradisi orang pintar secara turun temurung menjadi jejak peradaban Islam kepulauan. Tradisi ini mulai kurang di publikasikan oleh masyarakat saat ini karena dianggap bid'ah dan mitos, sementara sebagian masyarakat asli penduduk Tidore meyakini sebagai ilmu yang sangat bermanfaat bagi kemaslahatn hidupa manusia. Sebelum ada rumah sakit, para imam, ilmu falaq, para tabib, orang pintar, dan ahli nujum yang menjadi pusat kebutuhan spiritual masyarakat.

Islam Kepulauan yang tersebar di tengah masyarakat menjadi strategis yang mengobati masyarakat sebelum ada rumah sakit. Saat ini rumah sakit juga menghadapi berbagai masalah sehingga ada sebagian penyakit yang tidak bisa disebuhkan sehingga ilmu astrologi sebagai solusi terhadap persoalan yang 
dihadapi oleh rumah sakit modern. Semua ini membutuhkan penjelasan secara sistematis untuk mengungkap apa peran strategis ilmu astrologi Islam di tengah masyarakat. Untuk lebih dekat dengan ilmu astrologi Islam ini perlu dideskripsikan untuk mengidentifikasi jenis-jenis ilmu astrologi Islam kepulauan yang hidup di tengah masyarakat.

Catatan peneliti dapat di identifikasi ilmu astrologi Islam kepulauan memiliki kontribusi bagi masyarakat miskin yang tidak mampu memasukkan keluarganya di rumah sakit. Dalam kajian hanya sebagian yang akan dibahas sebagai sampel bahwa ilmu astrologi di kesultanan Tidore masih sangat berperan di tengah masyarakat Tidore. Berdasarkan hasil penjelajahan peneliti ditemukan beberapa jenis astrologi Islam di kota ini sebagai media dakwah, ilmu kesehatan, dan majelis ilmu pencerahan masyarakat yang berfungsi sebagai instrument sosial untuk meredam gejolak konflik sosial dengan modal sosial astrologi Islam.

Sebelum persentuhan dengan bangsa-bangsa Eropa ilmu astrologi Islam kepulauan mengenal 14 jenis ilmu astrologi yang digunakan dalam mencari rezki, musim pertanian, bintang mencari jodoh, masuk rumah baru, ilmu perang, ilmu kelautan dan kemaritiman. Berkaitan dengan pemilihan obat ramuan juga menggunakan ilmu astrologi sebagai petunjuk untuk menemukan ramuan yang cocok untuk menyembuhkan penyakit tertentu. Jika ilmu astrologi ini dapat diintegrasikan dengan ilmu astrologi modern maka dapat melahirkan wawasan baru dalam proses pengembangan ilmu pengetahuan di bidang Astrologi Islam modern.

Astrologi tidak difahami bukan sekedar ilmu perbintangan, tetapi lebih dari itu ilmu-ilmu sebelum datangnya peradaban Eropa umat Islam telah memiliki banyak terapi-terapi kesehatan jiwa yang sifatnya kemaslahatan umat Islam kepulauan. Ada beberapa ritual yang menjadi ciri dari Islam kepulauan dengan deskripsi sosial keagamaan sebagai berikut; setiap selesai shalat membaca ratib, berzikir, bertasbih dan untuk mencapai keselamatan hidup. Islam kepulauan juga memiliki ciri mulai dari lahir sampai ia meninggal semuanya serba doa selamat.

Akar historis Islam Indonesia ada dalam ikatan kebersamaan antar-raja dan antar-sultan, sedangkan untuk tradisi intelektual dan sosial itu tertuang dalam tradisi fiqih dan sufistik, lalu dikembangkan dalam Islam kepulauan dalam 
konteks lokal. Kearifan ini berkembang sejak tahun 90-an. Setelah imbas peradaban modern pada tahun 1990-an sampai sekarang ilmu kearifan lokal ini mulai tereleminasi oleh peradaban modern. Faktor penyebab pertama ditemukan listrik sehingga sistem kehidupan Islam kepulauan berubah dari pelita ke listrik.

Kondisi ini merubah wajah kehidupan Islam kepulauan menjadi lebih dinamis. Sejak masuknya listrik lebih berkembang lagi saat radio dan Televisi masuk desa membuat perubahan sosial pada Islam kepulauan. Dampaknya adalah Islam kepulauan lebih banyak mengakses berita TV dan Radio dan melupakan ilmu kearifan lokalnya. Salah satu budaya yang sangat terasa hilang adalah sifat gotong-royong, penyembuhan ritual, sifat individulisme makin tinggi, dan rasa persatuan, persaudaraan Islam kepulauan mulai terkikis oleh imbas budaya moderen.

Dalam kontek ini untuk menjaga, merawat dan melestarikannya ilmu kearifan lokal Islam kepulauan maka perlu festival kearifan lokal dan membuat konferensi untuk menjaga kedaulatannya di kawasan Islam kepulauan. Hal ini pernah dilakukan dalam dalam konferensi yang berlangsung selama dua hari ini bertema "Local Knowledge to Policy: Whose Evidence Matters". ${ }^{32}$ Tujuannya membangun wawasan tentang pentingnya pengakuan dan penghormatan terhadap peran pengetahuan kearifan lokal dalam pengembangan sektor pengetahuan di Indonesia yang sifat mono paradigm menajdi multi paradigma, sebagai basis untuk pembuatan kebijakan yang berkelanjutan.

Dalam acara yang digagas Pemerintah Australia melalui program Knowledge Sector Initiative (KSI) bekerjasama dengan Bappenas dan LIPI ini, Menteri Sofyan mengemukakan komitmen Bappenas mendukung pembangunan sektor pengetahuan termasuk di dalamnya pengetahuan lokal. Sebab, untuk menjawab tantangan pembangunan saat ini, pengetahuan yang dibutuhkan juga harus mengakar pada lokalitas masing-masing daerah dengan corak pengetahuan lokalnya yang selama ini mampu berkontribusi penataan terhadap ekosistem sosial sehat dan ilmu kesehatannya mampu berkontribusi terhadap umat Islam yang

32 Menteri PPN/Kepala Bappenas Sofyan Djalil menyebutkan bahwa local knowledge (pengetahuan lokal) dan local wisdom Indonesia harus lebih digali dan dijadikan basis kebijakan pada acara Konferensi Pengetahuan Lokal pada Selasa (12/04) di Auditorium Lembaga Ilmu Pengetahuan Indonesia (LIPI). 
berpenghasilan rendah. ${ }^{33}$ Berikut analisis ilmu astrologi Islam pesisir dan ilmu modern sebagai perspektif budaya.

\begin{tabular}{|c|c|}
\hline $\begin{array}{l}\text { kekurangan } \\
\text { fan lokal }\end{array}$ & $\begin{array}{l}\text { Kelebihan dan kekurangan } \\
\text { Ilmu Moderen }\end{array}$ \\
\hline $\begin{array}{l}\text { - Kesucian batin yang sangat di } \\
\text { dahulukan sebagai syarat dapat } \\
\text { menjalankan ilmu astrologi. }\end{array}$ & $\begin{array}{l}\text { - Kurang mengindahkan kejujuran } \\
\text { tetapi lebih menitip beratkan pada } \\
\text { kesucian batin, tapi lebih pada } \\
\text { kredibilitas profesionalisme. }\end{array}$ \\
\hline $\begin{array}{l}\text { - Niat dan tujuan pengobatan } \\
\text { untuk kemanusiaan dengan } \\
\text { dasar ikhlas bukan niat } \\
\text { berdasarkan materi. }\end{array}$ & $\begin{array}{l}\text { - Motivasinya biaya yang mahal } \\
\text { untuk menyembuhkan penyakit } \\
\text { tertentu akibat alat diaognosis } \\
\text { penyakit. }\end{array}$ \\
\hline $\begin{array}{l}\text { - Mampu mengobati penyakit } \\
\text { jasmani dan rohani. }\end{array}$ & $\begin{array}{l}\text { - Mampu mengobati penyakit } \\
\text { jasmani saja karena dasar } \\
\text { pengetahuannya berbasis jasmani. }\end{array}$ \\
\hline $\begin{array}{l}\text { - Murah dan dapat lebih banyak } \\
\text { motivasi membantu yang tidak } \\
\text { mampu berobat di rumah sakit }\end{array}$ & $\begin{array}{l}\text { - Mahal dan } \\
\text { dalam prose }\end{array}$ \\
\hline $\begin{array}{l}\text { - Media penyembuhan pada air } \\
\text { dan ramuan daunan sebagai } \\
\text { media utama, tabib kampung } \\
\text { tidak menggunakan alat } \\
\text { kedokteran yang mahal } \\
\text { sehingga pasien mampu } \\
\text { diobati tanpa menggunakan } \\
\text { biaya mahal. }\end{array}$ & $\begin{array}{l}\text { - Membutuhkan } \\
\text { kedokteran yang sangat mahal } \\
\text { sehingga pasien yang tidak } \\
\text { memiliki biaya perobatan tidak } \\
\text { bisa dilayani. }\end{array}$ \\
\hline $\begin{array}{l}\text { - Berkontribusi besar bagi } \\
\text { masyarakat miskin dan kurang } \\
\text { berkontribusi yang tidak punya } \\
\text { biaya }\end{array}$ & $\begin{array}{l}\text { - Berkontribusi besar bagi } \\
\text { masyarakat yang memiliki modal } \\
\text { besar. Rumah sakit modern } \\
\text { menggunakan biaya besar karena } \\
\text { fasilitas kedoteran dibeli dengan } \\
\text { harga yang mahal. }\end{array}$ \\
\hline - Biaya & - Biaya pendidikan dokter mahal \\
\hline
\end{tabular}

Dari tabel analisis kelebihan dan kekurangan astrologi modern dan tradisional masing-masing memiliki kelebihan dan kekurangan. Tetapi perhatian pada astrologi Islam belum banyak dijadikan sebagai kekuatan dalam membangun wawasan sebagai petunjuk dalam mengembangkan ilmu kesehatan jasmani dan rohani. 
Kearifan Islam pesisir di kesulatanan Tidore dalam aspek pengobatan tradisional dengan pengobatan modern memiliki keunggulan masing-masing yang jika di integrasikan memberikan dampak positif dalam sistem pengobatan jasmani dan rohani. Sampai saat realitas sosial menunjukkan bahwa Islam kepulauan masih dipengaruhi ilmu kesehatan tradisional. Rumah sakit hanya mampu mengobati penyakit Jasmani sementara penyakit jiwa, rohani, dan kemasukan jin lebih banyak ditangani oleh Dokter Kampung (Orang Tua-Tua).

Kontribusi dokter kampung sejak abat ke-15 telah berkontribusi terhadap kemanusiaan sampai saat ini sehingga kajian ilmu astrologi ini tetap menjadi kebutuhan masyarakat untuk menjadi petunjuk dalam memilih arah dan haluan hidup dalam menentukan kebijakan untuk mencapai sukses, sehat, dan selamat. ${ }^{34}$ Wawasan ini termasuk bagian dari perspektif integrasi keilmuan modern, etnoscience, dan science modern. Peretmuan etnometodologi melahirkan paradigm baru dalam kajian ilmu dakwah dan komunikasi.

\section{E. Kesimpulan}

Realitas sosial keagamaan Astrologi Islam Kepulauan diduga kuat berasal dari warisan keilmuan Sultan Nuku di Kesultanan Tidore. Standar kebenaran yang digunakan menggunan tradisi kebenaran berdasarkan keyakinan bukan berdasarkan fakta semata. Sehingga semakin tinggi etnografi keilmuan suatu masyarakat semakin tinggi pula pendekatan keyakinan sebagai parameter sebuah kebenaran dalam kehidupan sosial di kepulauan di Tidore. Peran astrologi sangat berkontribusi dalam merawat, menjaga dan mencegah tingkat kriminal dalam suatu masyarakat. Ditemukan bahwa peran astrologi Islam cenderung pada kekuatan spiritual sebagai tujuan hidup sedangkan science modern sebagai modal sosial untuk menggerakkan kekuatan akal. Jika kedua ini dapat diintegrasikan dengan metodologi baru maka dapat memecahkan persoalan sosial untuk merawat perbedaan cara pandang untuk menjelaskan suatu objek kebenaran.

\footnotetext{
${ }^{34}$ https://pusatkopibukukunojadul.wordpress.com/tag/astrologi/
} 
Daftar Pustaka

Ali Riasaty, Necessity of Rethinking about the Preventive Strategies of Addiction, International Journal of Community Based Nursing and Midwifery. Shiraz University of Medical Sciences, 2017.

Abdillah Yafi Aljawiy, Jejaring Sosial dan Dampak Bagi Penggunanya Jurusan Sistem Informasi, Fakultas Teknologi Infomasi Institut Teknologi Sepuluh Nopember Jurnal Ilmiah 2017.

Briyan Anugerah Pekerti, Pengaruh Jejaring Sosial Terhadap Kelakuan Seseorang Jurusan Kurikulum dan Teknologi Pendidikan Fakultas Ilmu Pendidikan, Universitas Negeri Semarang 2017.

Een Irianti, Fakultas Ilmu Dakwah dan Ilmu Komunikasi, UIN Syarif Hidayatullah Jakarta, Communicatus: Jurnal Ilmu Komunikasi, Vol. 1, No.1. Januari - Juli 2017.

Maswin M. Rahman, Mengenal Kesultanan Tidore, (Cet.I; Lembaga Kesultanan Keraton Limau Duko Kesultanan Tidore, 2006.

Risky Polisi (25 Tahun), Wawancara di rumahnya pada hari jumat 21 Juli 2017 jam 08:55 wit.

Nasrah, "Pengetahuan Manusia dan Epistemologi Islam", lihat juga Universitas Sumatera Utara Nasution, Khoiruddin, "Pengantar Studi islam" Yogyakarta: Tazzaff, 2009.

Muhammad Zainuddin, Filsafat Ilmu Perspektif Pemikiran Islam, Cet. II; Yogyakarta: Bayu Media, 2003.

Harun Nasution, Islam Rasional dan Gagasan dan Pemikiran, Cet. Bandung: Mizan, 1996.

Baqir Al-Shadr, Metode Tahliliy,(metode tajzi'iy), Metode ini berusaha menjelaskan ekspresi sosial dari segi pemahaman, pemaknaan, dan prilaku dengan memperhatikan prilaku manusia dalam ayat-ayat Al-Quran sebagaimana tercantum di dalam mushaf.

Koentjaraningrat dkk, Masyarakat Desa di Indonesia, Cet. XIV; Jakarta, Gramedia,1993.

Koentjaraningrat dkk, Metode-Metode Penelitian Masyarakat (Edisi Ketiga). Cet. VII; Jakarta: PT Gramedia Pustaka Utama,1987.

James P Spradley, Metode Penelitian Etnografi, Cet.II; Jakarta: Tiara Wacana, 2013.

Jogianto, Metodologi Penelitian Sistem Informasi, Cet.II; Jogyakarta: Andi, 2008.

Data yang dikutif pada BPS kota Tidore Kepulauan untuk semua kabupaten, penulis belum temukan data secara rinci perkecamatan tahun 2016.

Nani Jafar, Sejarawan Maluku Utara, http://kabarpulau.com/berita-pulau-tidoretitik-pembenaran-teori-ilmu-pengetahuan-.html. Diakses 31 Juli 2017.

Obat Herbal Penyakit Alergi Ikan Laut, Temuan Obat Ampuh dari Dasar Laut, http://www.dw.com/ id/temuanobat-ampuh-dari-dasar-laut/av-19246758.

Temuan Obat Ampuh dari Dasar Laut, http://www.dw.com/id/temuan-obatampuh-dari-dasar-laut/av-19246758

Maswin M. Rahman, Mengenal Kesultanan Tidore, Cet.I; Lembaga Kesultanan Keraton Limau Duko Kesultanan Tidore, 2006. 
Data Wawancara

Husen Maswara (56 Tahun), Wawancara, di kantor Fakultas Syari'ah tanggal 1 Agustus 2017 jam 10.30 wit

Ibnujarir (45 Tahun), Wawancara, di kantor rumahnya tanggal 19 Agustus 2017 jam 09.30 wit

Hasan (57 Tahun), Wawancara, di Rumahnya di Tomagoba tanggal 14 Agustus 2017 jam 18.30 wit.

Risky Polisi (25 Tahun), Wawancara di rumahnya pada hari jumat 21 Juli 2017 jam 08:55 wit.

Menteri PPN/Kepala Bappenas Sofyan Djalil menyebutkan bahwa local knowledge (pengetahuan lokal) dan local wisdom Indonesia harus lebih digali dan dijadikan basis kebijakan pada acara Konferensi Pengetahuan Lokal pada Selasa (12/04) di Auditorium Lembaga Ilmu Pengetahuan Indonesia (LIPI).

ww.ksi-indonesia.org/in/news/detail/pengetahuan-dan-kearifan-lokal-diharapkanjadi-basis-kebijakan. 